\title{
KONSELING INDIVIDUAL DENGAN PENDEKATAN GESTALT BAGI WARGA BINAAN PEMASYARAKATAN KASUS PEMBUNUHAN DI LAPAS KELAS II A YOGYAKARTA
}

\author{
Risma Dina \\ STKIP Budidaya Binjai \\ Email : rismadina817@gmail.com
}

\begin{abstract}
This study aims to describe the application of individual counseling with a gestalt approach for inmates in a homicide case. This research was conducted on 1 inmates at the Class II A prison in Yogyakarta. This type of research is a qualitative research with a case study model. Data collection techniques in this study used interviews, observation, and documentation studies. Then the data obtained were then analyzed descriptively by reducing the data, presenting the data and drawing conclusions from the data. The results showed that the application of individual counseling with a gestalt approach to homicide cases carried out in this study was effective in helping the counselee make decisions about the problems he faced with a marked decrease in the counselee's anxiety, the counselee was able to accept the reality that occurred by being able to accept himself, the counselee was also able to planning a better life, and being able to adjust and adapt to other inmates in prison.
\end{abstract}

Keywords : individual counseling, gestalt approach, homicides.

\begin{abstract}
ABSTRAK
Penelitian ini bertujuan untuk mendeskripsikan penerapan konseling individual dengan pendekatan gestalt bagi warga binaan pemasyarakatan pada kasus pembunuhan. Penelitian ini dilakukan pada 1 orang warga binaan pemasyarakatan di Lapas Kelas II A Yogyakarta. Jenis penelitian ini adalah penelitian kualitatif dengan model studi kasus. Teknik pengumpulan data dalam penelitian ini menggunakan metode wawancara, observasi, dan studi dokumentasi Kemudian data yang diperoleh lalu dianalisis secara deskriptif dengan cara mereduksi data, penyajian data dan penarikan kesimpulan dari data tersebut. Hasil penelitian menunjukkan bahwa penerapan konseling individual dengan pendekatan gestalt pada kasus pembunuhan yang dilakukan dalam penelitian ini efektif dalam membantu konseli mengambil keputusan terhadap permasalahan yang dihadapinya dengan ditandainya menurunnya kecemasan konseli, konseli mampu menerima kenyataan yang terjadi dengan mampu menerima diri sendiri, konseli juga sudah mampu merencanakan kehidupan yang lebih baik lagi, dan mampu menyesuaikan diri dan beradaptasi dengan warga binaan yang lain didalam lapas.
\end{abstract}

Kata Kunci : konseling individual, pendekatan gestalt, kasus pembunuhan 


\section{PENDAHULUAN}

Setiap manusia pasti pernah mengalami permasalahan didalam dalam hidupnya. Tetapi tidak semua individu mampu mampu mengatasi permasalahannya dan mampu mencari alternative pemecahan masalah sehingga terkadang mereka melakukan tindakan-tindakan diluar batas yang melanggar aturan hokum yang berlaku sehingga mengharuskan mereka menerima sanksi atas perbuatannya dengan menjalani statusnya sebagai warga binaan pemasyarakatan.

Warga binaan pemasyarakatan atau narapidana mulai menjalani hukumannya dan akan jauh dari orang-orang terdekatnya sejak vonis dijatuhkan, seorang narapidana akan memiliki perasaan perasaan yang melibatkan emosinya, misalnya perasaan jenuh, kesepian, sedih, takut, cemas, dan perasaan negatif lainnya yang akan berpengaruh terhadap penilaian dirinya. Kondisi yang tidak seimbang dan dengan segala perasaan negatif yang dimiliki oleh narapidana tidak jarang akan berdampak lebih buruk pada kondisi psikologisnya yaitu narapidana akan mengalami depresi, (Sum, Veronika, \& Pilosusan, 2017).

Kehidupan di lapas yang mengharuskan mereka beradapatasi dengan kehidupan yang selalu diawasi, penuh peraturan, kegiatan rutin dan persaingan dengan teman sekamar atau satu blok. (Anggit \& Ni, 2017). Ditambah lagi dengan hilangnya kebebasan, harga diri, perasaan malu, perasaan sedih, rasa bersalah, adanya sangsi social dan ekonomi merupakan permasalahan yang harus dijalani seorang narapidana (Gussak, 2009). Dan beban memikirkan pasangan, anak dan keluarganya, adanya penyakit, kondisi yang tidak nyaman, kebutuhan individu yang kurang diperhatikan karena harus bersikap kolektif, maka membuat kehidupan di Lapas penuh dengan tekanan dan beban. (Harding et al.,2019).

Para narapidana sangat membutuhkan bimbingan ataupun pembinaan. pembinaan pada dasarnya merupakan suatu aktivitas atau kegiatan yang dilakukan secara sadar, berencana, terarah, dan teratur secara bertanggungjawab dalam rangka menumbuhkan, meningkatkan, dan mengembangkan kemampuan serta sumber-sumber yang tersedia untuk mencapai tujuan. Dalam hal ini, pembinaan yang dilakukan dilembaga pemasyarakatan adalah pembinaan terhadap narapidana, baik narapidana yang dijatuhi pidana waktu tertentu maupun narapidana yang dijatuhi pidanaseumur hidup (Arfa, Nur, \& Monita, 2019).

Salah satu contoh pada kasus pembunuhan yang semakin sering banyak terjadi. melakukan pembunuhan menempatkan individu pada risiko yang sangat besar dan hukuman yang berat. Berdasarkan kondisi ini, suatu hal yang menarik dan penting untuk mengetahui dinamika psikologis yang melatarbelakangi individu melakukan pembunuhan, (Octavia, 2021).

Salah satu yang dapat diberikan kepada narapidana adalah dengan memberikan layanan konseling yang dapat membantu warga binaan pemasyarakatan mampu megambil keputusan terhadap permasalah yang dihadapinya. Karena tidak semua warga binaan pemasyarakatan (narapidana) mampu melupakan setiap kejadian, kesalahan yang telah dia lakukan selama hidupnya yang menyebabkan dia mendapatkan hukuman.

Layanan konseling diharapkan bisa membantu masyarakat dalam setiap aspek kehidupan, terutama dalam menghadapi problematika hidup. Menurut Willis (2013) konseling individu adalah pertemuan konselor dengan konseli secara individual, dimana terjadi hubungan konseling yang bernuansa rapport dan konselor berupaya memberikan bantuan untuk pengembangan pribadi konseli dan konseli dapat mengantisipasi masalah-masalah yang dihadapinnya.

Selain itu Prayitno \& Amti (2015) juga mengemukakan bahwa konseling bertujuan untuk membantu individu membuat pilihanpilihan, penyesuaian penyesuaian dan interpretasi dalam hubungannya dengan situasi 
tertentu, dan ntuk membantu orang-orang menjadi insan yang berguna.

Penelitian yang dilakukan oleh Sari (2020). hasil penelitian menunjukkan bahwa dari pelayanan konseling individual mampu merubah perilaku, mampu mengatasi rasa kecemasan, berfikir positif, dan mampu mengatasi perasaan tertekan,kecewa, dan rasa ketidak mampuan yang menghinggapinya.

rendah diri terhadap dirinya.

Penelitian yang dilakukan oleh Prianti (2020) hasil penelitian menunjukkan bahwa layanan konseling individual dengan pendekatan humanistik sangat berpengaruh terhadap warga binaan pemasyarakatan terbukti dari perubahan diri klien yaitu, menurunnya kecemasan klien, mempunyai rencana hidup yang praktis,pragmatis, dan berguna, mampu menerima diri sendiri, mampu menyesuaikan diri, mampu memecahkan masalahnya sendiri, dan konseli juga termotivasi melakukan proses konseling yang meliputi kesukarelaan kesadaran akaan adanya masalah, dan kesadaran membutuhkan bantuan orang lain untuk menyelesaikan masalah yang dihadapi.

Maka dari itu diperlukan konselor dalam membantu narapidana dalam mengatasi permasalahan yang dihadapinya. Penelitian yang dilakukan oleh Asnidar (2010) menunjukkan bahwa peran konselor dalam memberikan bimbingan agama Islam terhadap narapidana di Lembaga pemasyarakatan klas II B anak Pekanbaru adalah sudah berperan, dimana hasil dari rekapitulasi data dapat jawanban $76,82 \%$ dari responden.

Dalam melakukan proses konseling tentu saja dibutuhkan pendekatan konseling yang sesuai untuk membantu konseli dalam memecahkan permasalahan yang dihadapinya. Dalam penelitian ini peneli menggunakan pendekatan gestalt dengan teknik empathy chair dianggap sesuai dengan permasalahan yang dialami konseli yaitu pada kasus pembunuhan.

Pendekatan Gestalt adalah terapi humanistik eksistensial yang berlandaskan premis, bahwa individu harus menemukan caranya sendiri dalam hidup dan menerima tanggungjawab pribadi jika individu ingin mencapai kedewasaan. Asumsi ini didasarkan pada bahwa manusia dalam kehidupannya selalu aktif sebagai suatu keseluruhan.Setiap individu bukan semata-mata merupakan penjumlahan dari bagian-bagian organ-organ seperti hati, jantung, otak, dan sebagainya, melainkan merupakan suatu koordinasi semua bagian tersebut. Manusia aktif terdorong kearah keseluruhan dan integrasi pemikiran, perasaan, dan tingkah lakunya, (Febrini, 2011).

Gestalt memandang bahwa pendekatan eksistensial juga dipengaruhi oleh suatu pijakan bahwa konseli yang datang kepada konselor sedang dalam kondisi krisis eksitensial dan perlu belajar bertanggungjawab atas eksistensinya sebagai manusia (Jones, 2011).

Melihat paparan permasalahan diatas, maka peneliti tertarik dalam melakukan penelitian yang berjudul konseling individual bagi warga binaan kasus pembunuhan di lapas kelas II Yogyakarta.

\section{METODE PENELITIAN}

Jenis penelitian ini adalah penelitian kualitatif. Menurut Sugiyono (2019) penelitian kualitatif adalah penelitian yang digunakan untuk meneliti kondisi objek yang alamiah dan data yang di peroleh cenderung data kualitatif dengan teknik analisis data yang bersifat kualitatif.

Penentuan sample didasarkan atas pertimbangan oleh Pembina Lapas dengan memilih narapidana yang dapat dijadikan konseli dalam mengikuti proses konseling. Selanjutnya untuk mendapatkan data yang sesuai, maka peneliti menggunakan beberapa metode untuk memperoleh data-data yang benar dan lengkap.

Metode yang digunakan diantaranya ialah :

1. Wawancara

Wawancara digunakan sebagai teknik pengumpulan data apabila peneliti ingin melakukan studi pendahuluan untuk menemukan permasalahan yang harus 
diteliti, dan apabila peneliti ingin mengetahui hal-hal dari responden yang lebih mendalam dan jumlah respondennya Sedikit (Sugiyono, 2019).

2. Observasi

Metode observasi adalah metode pengumpulan data yang dilakukan dengan cara mengamati dan mencatat secara sistematik gejala-gejala yang di selidiki (Narbuko \& Achmadi (2013).

3. Studi dokumentasi

Metode dokumentasi merupakan teknik pengumpulan data dengan mempelajari catatan-catatan mengenai data pribadi responden, (Fathoni, 2001).

Setelah itu peneliti melakukan analisis data dengan cara berikut ini :

a. Reduksi data

Reduksi data merupakan merangkum kembali catatan lapangan, memilih hal-hal pokok, dengan lebih memfokuskan kepada hal-hal yang penting, dengan demikian data yang telah direduksi akan memberikan gambaran yang lebih jelas dan mempermudah peneliti untuk melakukan pengumpulan data selanjutnya.

b. Penyajian Data (Display Data)

Setelah data direduksi, maka langkah selanjutnya adalah mendisplaykan data. Dengan mendisplay data maka akan memudahkan untuk memahami apa yang terjadi, merencanakan kerja selanjutnya berdasarkan apayang telah dipahami.

c. Penarikan kesimpulan (Verifikasi)

Langkah ke empat dalam analisis kualitatif yaitu verifikasi dan penarikan kesimpulan. Kesimpulan dalam penelitian kualitatif merupakan temuan baru yang sebelumnya belum pernah ada, temuan dapat berupa deskripsi atau gambaran suatu obyek yang sebelumnya masih remang-remang atau gelap sehingga setelah diteliti menjadi jelas.

\section{HASIL DAN PEMBAHASAN}

Konseling individual dilakukan dengan menggunakan pendekatan konseling Gestalt yang berfokus pada kesadaran konseli akan realitas. Konselor membangun kesadaran konselor dengan membawa konseli pada konsep here and now. Konselor juga menyadarkan bahwa konseli harus bertanggung jawab sendiri atas pengalamannya, dan unfinished bussiness konseli kepada korban akan diselesaikan melalui teknik empathy chair.

Teknik empathy chair merupakan teknik yang digunakan untuk mengajak klien agar dapat mengungkapkan perasaan yang terpendam dalam dirinya melalui proyeksi dengan permainan peran. Pada dasarnya teknik ini adalah teknik bermain peran yang keseluruhan perannya dilakukan oleh satu orang. Melalui teknik ini diharapkan proyeksi pada permainan peran dapat dimunculkan ke permukaan sehingga klien bisa mengalami konflik lebih penuh. Konselor membawa konseli pada kondisi imaginer berbicara dengan korban kemudian mengungkapkan perasaan-perasaan bersalahnya. (Corey, 2011).

Pertemuan konseling dilakukan 2 kali pertemuan secara singkat adapun langkahlangkah proses konseling yang dilakukan adalah sebagai berikut :

1) Konseling dilakukan dalam tiga tahapan. Sesi pertama berfokus pada pembangunan hubungan konseling, memperjelas dan mendefinisakan masalah, membuat penafsiran dan penjajakan, menegosiasikan kontrak konseling,

2) Pada sesi kedua berfokus pada penjelajahan dan eksplorasi masalah, dan penerapan pendekatan dan teknik konseling,

3) Dan sesi ketiga dengan menanyakan perkembangan setelah melakukan sesi konseling pertama dan kedua (pengambilan keputusan).

\section{Konseling pada pertemuan hari pertama}

Konselor berusaha menyambut
kedatangan konseli dengan baik, dengan


menanyakan identitas (nama konseli). Dalam pertemuan di hari pertama ini tampak konseli masih sulit untuk diajak berinterakasi. Dan lebih banyak berdiam diri. Tetapi konselor tetap melakukan penjajakan terhadap apa yang sebenernya dialami konseli.

Konseli sudah mau membuka diri terhadap dirinya, konseli sudah mulai tampak banyak berbicara dan mengemukakan permasalahan yang terjadi. Sehingga didapatkan sebuah akar permasalahan konseli yaitu pada perasaan bersalah dan menyesal karena telah membunuh seseorang.

Selanjutnya membawa konseli pada penerapan teknik empathy chair. Konseli dihadapkan dengan kursi kosong dan diminta untuk membayangkan jika di kursi itu sedang berada korban kemudian konselor meminta konseli untuk mengungkapkan seluruh persaan kepada sahabatnya, konseli dapat menyampaikan apa saja yang ingin di sampaikan kepada korban.

Pada tahapan ini konseli sudah mampu mengambil keputusan terhadap masalah yang dihadapinya, konseli sudah mampu menerima kenyataan yang terjadi, dengan memaafkan dirinya sendiri dan tidak akan terus larut dalam kesedihan karena perasaan bersalahnya.

Tetapi dalam hal ini konselor akan melakukan follow up untuk mengetahui perkembangan konseli dengan melakukan konseling lagi dipertemuan ke 2, dan konseli menyetujuinya.

\section{Konseling pada pertemuan hari kedua}

Pada tahap ini tampak konseli sudah mulai berubah, dia juga sudah menunjukkan sikap yang terbuka dengan kembali menyapa konselor, hal ini menunjukkan perbedaan pada pertemuan dihari pertama yang dilakukan.

Proses konseling yang kedua lebih jauh berbeda dikarenakan konseli . perkembangan konseli jauh lebih pesat dengan ditandainya saat proses akhir konseling, konseli sudah lebih memahami bagaiamana perencanaan hidup yang lebih baik lagi kedepannya. Yang dimana pada pertemuan konseling pertama konseli hanya mampu menyadari kesalahan nya saja, tanpa ada perencamaan hidup kedepannya. Konseli akan mempergunakan waktunya untuk hal yang lebih berguna lagi.

Selain itu peneliti melakukan follow up (tindak lanjut) dari hasil konseling dengan melakukan wawancara dengan Pembina lapas terkait mengetahui perkembangan konseli selama di dalam Lapas. Pembina lapas mengungkapkan sebelum dilakukan konseling kepada konseli, konseli memang suka menyendiri ketika didalam ruangan, sulit berinteraksi dengan temannya didalam 1 ruangan.

Adapun keterbatasan dalam pelaksanaan konseling ini yaitu sebagai berikut :

1. Proses pelaksanaan konseling tetap diawasi oleh petugas lapas, sehingga narapidana merasa tidak bebas dalam menyampaikan informasi.

2. Konselor tidak dapat memantau secara langsung bagaimana perkembangan konseli didalam ruangan karena memang tidak diberikan izin oleh petugas lapas, sehingga untuk melihat perkembangan konseli konselor harus melakukan proses konseling beberapa kali dan bertanya langsung kepada petugas lapas.

3. Keterbatasan ruangan dalam melakukan konseling, sehingga proses konseling hanya dilakukan pada tempat yang seadanya didepan ruangan petugas atau Pembina lapas.

\section{KESIMPULAN}

Permasalahan di atas menunjukkan bahwa dimasa lalu, konseli memiliki perasaan bersalah yang sangat kuat terhadap korban Dimasa lalu konseli telah melakukan tindakan pembunuhan karena untuk membela dirinya. Konseli tidak memiliki kesempatan untuk menyampaikan perasaan-perasaannya secara langsung kepada korban. Akibatnya pada kehidupannya yang 
sekarang, konseli dihantui perasaan bersalah yang begitu mendalam. Menurut Perls dalam teorinya Gestalt, apabila adanya masalah dimasa lalu yang belum terselesaikan maka akan menimbulkan masalah yang baru dimasa mendatang, inilah yang dimaksud dengan unfinished business.

Unfinished business yang dialami oleh konseli yaitu perasaan bersalah yang sangat mendalam kepada. Penyelesaian unfinished business ini dilakukan dengan membawa kesadaran here and now konseli ke dalam proses konseling. Selanjutnya konselor menggunakan teknik kursi kosong sebagai penyelesaian masalah si konseli.

Hasil penelitian menunjukkan bahwa penerapan konseling individual dengan pendekatan gestalt pada kasus pembunuhan yang dilakukan dalam penelitian ini efektif dalam membantu konseli mengambil keputusan terhadap permasalahan yang dihadapinya dengan ditandainya menurunnya kecemasan konseli, konseli mampu menerima kenyataan yang terjadi dengan mampu menerima diri sendiri, konseli juga sudah mampu merencanakan kehidupan yang lebih baik lagi, dan mampu menyesuaikan diri dan beradaptasi dengan warga binaan yang lain didalam lapas.

Konseling dilakukan sebanyak $2 \mathrm{x}$ pertemuan, selain itu peneliti melakukan follow up (tindak lanjut) dari hasil konseling dengan melakukan wawancara dengan Pembina lapas terkait mengetahui perkembangan konseli selama di dalam Lapas. Pembina lapas mengungkapkan sebelum dilakukan konseling kepada konseli, konseli memang suka menyendiri ketika didalam ruangan, sulit berinteraksi dengan temannya didalam 1 ruangan.

Tetapi setelah dilakukan konseling, tampak perubahan yang signifikan dari konseli, konseli sudah mulai mampu menyesuaikan diri dengan teman 1 ruangan, dan konseli juga sudah mulai banyak berbicara dan tidak menyendiri lagi.
Selain itu konselor juga sangat mengharapkan agar Pembina lapas juga memberikan perhatian khusus kepada para warga binaan pemasyarakatan atau narapidana agar mereka tetap dipantau bagaimana perkembangan dirinya, karena tidak semua narapidana mampu untuk beradaptasi dengan baik, dan mampu mengatasi setiap permasalahan yang dihadapinya. Apalagi setelah mereka keluar dari lapas tentu saja mereka harus mempersiapkan dirinya untuk dapat menyesuaikan dilingkungan masyarakat, karena nantinya tidak semua masyarakat, ataupun keluarga mampu menerima mereka dengan baik.

\section{REFERENSI}

Anggit, F., \& Ni, A. (2017). Tingkat Stres dan Harga Diri Narapidana Wanita Di Lembaga Pemasyarakatan Kelas II A Kota Bogor. Jurnal Riset Kesehatan, 9(2), 26-33.

Arfa, N., Nur, S., \& Monita, Y. (2019). ola Pembinaan Terhadap Narapidana Seumur Hidup Dalam Kebijakan Implementasinya. Jurnal Sains Sosio Humaniora, 3 (2), 250-260.

Asnidar. (2010). Peran Konselor Dalam Memberikan Bimbingan Agama Islam Terhadap Narapidana Dilembaga Pemasyarakatan Klas Ii B Anak Pekanbaru. Skripsi. Riau : Universitas Islam Negeri Sultan Syarif Qasim.

Corey, G. (2011). Theory and Practice of Counseling and Psychotherapy. California State University : California.

Harding, D. J., Morenoff, J. D., \& Wyse, J. J. B. (2019). On the outside: Prisoner reentry and reintegration. University of Chicago Press.

Fathoni, A. (2001). Metodologi Penelitian, Jakarta, Rineka Cipta.

Febrini, D. (2011). Bimbingan Konseling, Yogyakarta: Teras. 
Gussak, D. (2009). Comparing the effectiveness of art therapy on depression and locus of control of male and female inmates. The Arts in Psychoterapy, 36, 202-207.

Jones R. N. (2011). Teori \& Praktik Konseling dan Terapi, (Yogyakata: Pustaka Pelajar.

Narbuko, C \& Achmadi, A. (2013). Metodologi Penelitian. Jakarta : Bumi Aksara.

Octavia, C.F. (2021). Dinamika Psikologis Pembunuh Usia Dewasa: Sebuah Studi Kasus. Jurnal Psikologi Konseling. 18(1), 895-909.

Prayitno, \& Amti, E. (2015). Dasar-Dasar Bimbingan dan Konseling. Jakarta : Rineka Cipta.

Prianti, E.R. (2020). Layanan Konseling Individual Dengan Pendekatan Humanistik Bagi Warga Binaan Pemasyarakatan Kasus Pembunuhan Di Lembaga Pemasyarakatan Perempuan Kelas II A Way Hui Kota Bandar Lampung. Skripsi. Lampung : UIN Raden Intan.

Sari, E.A. (2020). Penerapan Konseling Individual Dalam Meningkatkan Rasa Percaya Diri (Studi Kasus Pada Warga Binaan Pemasyarakatan Di Lembaga Pemasyarakatan Perempuan Kelas II A Bandar Lampung. Lampung : UIN Raden Intan.

Sugiyono. (2019). Metode Penelitian Kuantitatif, Kualitatif, dan R \& D. Bandung : Alfabeta.

Sum, E.E.D., Veronika, M., \& Pilosusan, S. (2017). Kehidupan Narapidana di LAPAS (Lembaga Pemasyarakatan). Indonesian Journal of School Counseling. 2(2), 20-25.
Willis, S.S. (2013). Konseling Individual Teori dan Praktek.Bandung : Alfabeta. 